\title{
Resistance Spot Welding of Steel Sheets
}

Milan Brožek

Department of Material Science and Manufacturing Technology, Faculty of Engineering, Czech University of Life Sciences Prague, Kamýcká 129, 16521 Praha 6 - Suchdol, Czech Republic, E-mail: brozek@tf.czu.cz

Resistance welding ranks among progressive and in practice often used manufacturing techniques of rigid joints. The basis of this method is in the utilization of the Joulean heat, which arises at the passing of current through jointed sheets at collective influence of compressive force. The aim of the carried out tests has been to evaluate the rupture force of spot welded steel sheets of various thickness using short-time spot welding and long-time spot welding. For test specimens welding the parameters recommended by the spot welder producer were used. After welding all assemblies were loaded using the universal test machine up to their rupture. The rupture force was written down. From the carried out tests it follows that welding of sheets of the thickness $1+1 \mathrm{~mm}, 1+2 \mathrm{~mm}, 1+$ $3 \mathrm{~mm}, 1+4 \mathrm{~mm}$ and $2+2 \mathrm{~mm}$ the rupture force value differences of short-time spot welding compared to longtime spot welding are practically negligible. But at the specimens of thickness $2+3 \mathrm{~mm}, 2+4 \mathrm{~mm}, 3+3 \mathrm{~mm}, 3+$ $4 \mathrm{~mm}$ and $4+4 \mathrm{~mm}$ considerable differences were determined. The part of this tests evaluation was also the assessment of the tested assemblies failed pieces.

Keywords: resistance welding; steel sheet; laboratory test; spot welds shear testing

\section{Acknowledgement}

Supported by the Internal Grant Agency of the Czech University of Life Sciences Prague, Prague, Czech Republic; Project No. 2014:31140/1312/3133 titled “Influence of environmental conditions on constructional bonds".

\section{References}

[1] BROŽEK, M., NOVÁKOVÁ, A. (1995). Porovnání jednostranných nýtů s trnem různých výrobců (Comparison of blind rivets of different producers). In.: XXXVI. konference kateder částí a mechanismů strojů (díl 1). VUT, 13.-14. June. Brno. 37-40.

[2] BROCKMANN, W. et al. (2009). Adhesive bonding: materials, applications and technology. Weinheim, Wiley$\mathrm{VCH}$.

[3] BROŽEK, M. (2014). Technical-economical evaluation of beech plywood bonding. In.: 13th International Scientific Conference Engineering for Rural Development. 29.-30. May, Latvia, Jelgava, 168-173.

[4] BROŽEK, M. (2013). Technical-economical evaluation of plywood bonding. In.: 5th International Conference "Trends in Agricultural Engineering”. 3.-6. September. Czech University of Life Sciences Prague. 100-105.

[5] BROŽEK, M. (2013). Optimization of adhesive layer thickness at metal bonding using quick-setting adhesives. Manufacturing Technology. 13. 4. 419-423.

[6] BROŽEK, M. (2013). Soldering steel sheets using soft solder. Research in Agriculture Engineering. 59. 4. 141146.

[7] BROŽEK, M. (2013). Soldering sheets using soft solders. Acta Universitatis Agriculturae et Silviculturae Mendelianae Brunensis, 61. 6. 1597-1604.

[8] NIPPES, E. F. (1983). Metals Handbook. Vol. 6., Welding, Brazing, and Soldering. Metal Park, ASM International. 1152.

[9] RUŽA, V. (1988). Pájení. (Soldering). Prague. SNTL. 456.

[10] BLAŠČÍK, F. et al. (1987). Technológia tvárnenia, zlievárenstva a zvárania. (Technology of Forming, Founding and Welding). Bratislava. ALFA. 832.

[11] BROŽEK, M. (2012). Wear resistance of multi-layer overlays. In.: 11th International Scientific Conference Engineering for Rural Development. 24.-25. May. Latvia. Jelgava. 210-215.

[12] BROŽEK, M. (2011). Layer number influence on weld deposit chemical composition. In.: 10th International Scientific Conference Engineering for Rural Development. 26.-27. May. Latvia. Jelgava. 393-397.

[13] HUDEC, Z. (2012). Gas Metal Rapid Arc Welding Potential. Manufacturing Technology. 12. 13. 113-118.

[14] KOLAŘÍKOVÁ, M., KOLAŘÍK, L., KOVANDA, K., HRABINA, R. (2013). Welding of Normalized Heat Treated Steels S355NL Large Thicknesses by Method FCAW. Manufacturing Technology. 13. 2. 181-188.

[15] KOVANDA, K., HOLUB, L., KOLǍ̌ÍK, L., KOLǍ̌ÍKOVÁ, M., VONDROUŠ, P. (2012). Experimental Verification of FEM Simulation of GMAW Bead on Plate Welding. Manufacturing Technology. 12. 12. 30-33. 
[16] KRAMÁR, T., KOLǍ̌ÍK, L., KOLAŘÍKOVÁ, M., SAHUL, M., POSPÍŠIL, D. (2014). Capacitor Discharge Welding of Aluminium Studs. Manufacturing Technology. 14. 2. 199-206.

[17] MEŠKO, J., ZRAK, A., MULCZYK, K., TOFIL, S. (2014). Microstructure Analysis of Welded Joints after Laser Welding. Manufacturing Technology. 14. 3. 355-359.

[18] NOVOTNÝ, J., HONZÍKOVÁ, J., PILOUS, V., STRÁNSKÝ, K. (2015). Properties of Welded Joints in Power Plant. Manufacturing Technology. 15. 6. 1028-1032.

[19] PODREZ-RADZISZEWSKA, M. (2011). Weldability problems of the technical AW7020 alloy. Manufacturing Technology. 11. 11. 59-66.

[20] ČSN EN ISO 4063 (2010). Svařování a přibuzné procesy - Přehled metod a jejich číslování (Welding and allied processes - Nomenclature of processes and reference numbers). ČNI.

[21] LIU, H., WANG, H., ZHANG, X., LI, C. (2012). Optimization of parameters and research on joint microstructure of resistance spot welding of 201stainless steel. Advanced Materials Research. Volume 418-420, 1359-1363. 2nd International Conference on Advances in Materials and Manufacturing, ICAMMP 2011. Guilin. China. 16.-18. December, 2011.

[22] LIU, H., XU, X., ZHANG, X. (2013). Optimization of parameters and research on joint microstructure of resistance spot welding for 316 stainless steel. Advanced Materials Research. Volume 652-654, 2326-2329. 2012. 3rd International Conference on Advances in Materials and Manufacturing Processes, ICAMMP 2012. Beihai. China. 22.-23. December, 2012.

[23] PEASURA, P. (2011). The influence of welding parameters on effected the complete for resistance spot welding on mild steel. Advanced Materials Research. 214. 113-117. International Conference on Key Engineering Materials, ICKEM 2011. Sanya. China. 25.-27. March, 2011.

[24] Pouranvari, M. (2011). Effect of resistance spot welding parameters on the HAZ softening of DP980 ferrite-martensite dual phase steel welds. World Applied Sciences Journal. 15. 10. 1454-1458.

[25] TYLECOTE, R. F. (1941). The Spot Welding of Light Alloys.

[26] Tentative Standards and Recommended Practices and Procedures for Spot Welding of Aluminium Alloys (1942). New York. American Welding Society. 48.

[27] HAYAT, F., SEVIM, I. (2012). The effect of welding parameters on fracture toughness of resistance spot-welded galvanized DP600 automotive steel sheets. International Journal of Advanced Manufacturing Technology. 58. 9.12. February. 1043-1050.

[28] SVÍTIL, A. (1980). Odporové bodové svařování tenkých pozinkovaných ocelových plechů (Resistance spot welding thin galvanised steel sheets). Praha, b.t. 210. In Czech.

[29] WANG, Z., WANG, Y., ZHANG, D. (2013). Optimization on parameters of resistance spot welding process for galvanized steel plate. Advanced Materials Research. 658, 178-181. 2012 International Conference on Materials and Manufacturing Research. ICMMR 2012. 19.-20. December, 2012.

[30] LI, R. X. (2012). Quality monitoring of resistance spot welding based on process parameters. Energy Procedia. 14, 925-930. 2011, ICAEE 2011. Bangkok. Thailand. 27.-28. December, 2011.

[31] YOUNGER, A., GOURD, L. M., JUBB, J. E. M. (1966). An Investigation into the Fatigue Properties of a Single Spot Weld Lap Joint Cranfield. College of Aeronautics. 18.

[32] ČSN EN ISO 4063 (2010). Svařování a př́buzné procesy - Přehled metod a jejich číslování (Welding and allied processes - Nomenclature of processes and reference numbers). ČNI.

[33] HIPPERSON, J., WATSON, T. (1950). Resistance Welding.

[34] HIPPERSON, J. Recommended Machine Settings for Resistance Welding.

[35] HOLÁSEK, J. (1968). Odporové zváranie (Resistance welding). Bratislava. Slov. vydav. technické literatury.

[36] ZHANG, H., SENKARA, J. (2012). Resistance Welding: Fundamentals and Applications. 2nd Edition. Boca Raton. CRC Press.

[37] BROŽEK, M. (2015). Resistance spot welding of steel sheets of different thickness. In.: 14th International Scientific Conference on Engineering for Rural Development. 20.-22. May. Latvia. Jelgava. 72-77.

[38] BROŽEK, M. (2014). Working variables optimization of resistance spot welding. Manufacturing Technology. 14. 4. 522-527.

[39] ČSN EN ISO 14273 (2003). Rozměry vzorku a postup zkoušení střihem odporových bodových, švových a výstupkových svarů (Specimen dimensions and procedure for shear testing resistance spot, seam and embossed projection welds). ČNI.

[40] ČSN EN 1465 (2009). Lepidla - Stanovení pevnosti ve smyku při tahovém namáhání přeplátovaných lepených soustav (Adhesives - Determination of tensile lap-shear strength of bonded assemblies). ČNI. 